\title{
The Eurasian Economic Union as an Element of the Belt and Road Initiative ${ }^{1}$
}

\author{
Katarzyna Czerewacz-Filipowicz \\ Ph.D., Associate Professor, China and Central-Eastern Europe Institute of Logistics \\ and Service Science, Faculty of Engineering Management \\ Bialystok University of Technology, Bialystok, Poland, e-mail: k.czerewacz@pb.edu.pl
}

\section{Abstract}

The New Silk Road, or actually the Belt and Road Initiative (BRI), is a Chinese concept aimed at facilitating international trade between China, Europe and Africa as well as building a new international economic order and security system. More than 60 countries belonging to various economic groupings with different levels of economic development and economic openness have been involved in the BRI.

Many branches of the BRI run through the countries belonging to the Eurasian Economic Union (EAEU). This is mainly the Trans-Siberian corridor, being the northern branch of the Route, which is being developed in the most dynamic way and is the most exploited among all railway connections between China and Europe.

In theory, the EAEU and its customs union between Belarus, Kazakhstan and Russia should allow the easy transit of goods between Europe and Asia. Transport infrastructure, much better than in the case of the other BRI railway branches, seems to be an additional advantage. Unfortunately, political and structural factors, as well as the embargo imposed by Russia on many goods originating in Western Europe, significantly limit the possibilities of using this transport route.

The aim of the article is to examine the potential of the Eurasian Economic Union as part of the Belt and Road Initiative and assess the possibility of using the transport corridor running through the territory of the EAEU within the BRI. We will also identify the main determinants that will affect the development of transport and logistics corridors running through the EAEU in the future.

Keywords: Eurasian Economic Union (EAEU), Belt and Road Initiative (BRI), New Silk Road (NSR), international trade.

JEL: F15, F50, L92, M21

1 Research carried out under work No. S / WZ / 1 / 2014 and financed from the resources for science of the Ministry of Science and Higher Education. 


\section{Introduction}

The processes of international regional integration are one of the prominent tendencies in the contemporary global economy and they have resulted in the emergence of a new level of order, situated between a domestic and global order (De Lombaerde 2007). At present, it is not possible to answer the question of whether we are dealing with a global integration process or with activities disintegrating the global economy (Miklaszewski and Molendowski 2009, p. 12). By means of exploring regionalism, we can point out the elements that can both unite and divide the contemporary world economy (Bhagwati and Panagariya 1996). However, individual integration initiatives are certain to strongly influence each other and determine the directions of development; they also often overlap one another.

In the presented research process, the following issues are taken up:

- attempts to determine the potential of the Eurasian Economic Union (EAEU) as part of the Belt and Road Initiative (BRI),

- verification of the attractiveness of the EAEU from the perspective of the BRI,

- an assessment of the determinants affecting the participation of the Eurasian Economic Union in the Belt and Road Initiative,

- pointing out and assessing the main barriers in the development of the BRI's land in the EAEU.

The main research question formulated in this paper is: What conditions must be met for land branches of the BRI running through the EAEU to get developed?

The answer to this question is important from the point of view of a number of European countries, mainly the countries of Central and Eastern Europe, the EAEU countries, and the western and north-western Chinese provinces. The land branch of the Belt and Road Initiative may become an important factor in the economic development of the indicated countries and regions.

The aim of the article was to examine the potential of the Eurasian Economic Union as part of the Belt and Road Initiative and to assess the possibility of using the transport corridor running through the territory of the EAEU as part of the BRI, as well as identify the main determinants that will affect the development of transport and logistics corridors running through the EAEU in the future. An important element of the research process was to identify the main barriers to the development of transport corridors of the BRI, whose route runs through the EAEU, from structural, economic, infrastructural, administrative and legal, as well as political perspectives.

Ian Bond (Bond 2017, p. 1) indicates three main integration projects in the Eurasian landmass: the European Union, the Eurasian Economic Union (EAEU) and China's Belt and Road Initiative, which overlap each other. The mutual relationships between these three structures are complicated but important for the future economic development of all Eurasian states. The three initiatives mentioned differ significantly in terms of economic potential, size, the degree of institutionalization and the origin 
of their inception. However, all of them aim at the economic development of the participating countries.

From China's perspective, the rail branch of the BRI is mainly an initiative aimed at making the western and north-western provinces of the country more dynamic. In the case of the countries of the EAEU, the land branch of the BRI could become the important driving factor of their economic development they need so much. Experts from the Eurasian Development Bank underline that for the EAEU countries, the BRI is going to become a solution to logistics and transport problems, mainly in the area of landlocked regions, such as the Russian Urals, Siberia and all of Central Asia (Vinokurov et al. 2018; Libman 2016).

The territorial scope of the Belt and Road Initiative is the largest among indicated integration initiatives and currently covers about 60 countries, including the countries belonging to the Eurasian Economic Union and the European Union. By contrast, the institutional architecture of the BRI is incomparably smaller than the EU or even the EAEU.

A challenge for all three integration initiatives is to create a harmonious and stable relationship among themselves. In this case, the EAEU and China have agreed on the convergence between the BRI and the EAEU (Bond 2017, pp. 1-4). In turn, the EU and China are major economic partners and are looking for opportunities in the BRI (Bond 2017, pp. 1-2). The relationships between the EAEU and the EU - in fact, the lack of these relationships - pose the biggest problem, challenge and barrier in the development of the land branches of the BRI.

\section{Literature review}

The Eurasian Economic Union integrates five countries: Armenia, Belarus, Kazakhstan, Kyrgyzstan and the Russian Federation. Ultimately, it should lead the member countries to the stage of an economic union (Договор о Евразийском экономическом союзе 2014). At present, three of the five EAEU Member States, that is, Belarus, Kazakhstan and Russia, form a customs union, and the other two countries are striving for this stage. The ability and competence to create external relations distinguishes the EAEU from other integration groups in the post-Soviet area. The EAEU integration concept in itself concerns not only internal aspects, but it may take the form of an external strategy (Czerewacz-Filipowicz 2016; Czerewacz-Filipowicz and Konopelko 2017).

The concept of creating the EAEU was presented by Vladimir Putin in an article for the "Izvestia" daily in October 2011. The EAEU, according to Putin, may "become so powerful an organization that it can play the role of a connector "between Europe and the dynamic region of Asia and the Pacific" (Putin 2011). In connection with the above, the EAEU may perform a number of new functions that no organization in the post-Soviet area previously did. From the perspective of the member 
states' participation in the Belt and Road Initiative, the most important are the relationships of the EAEU with China and the European Union. The main land axis of the BRI concerns China's network of connections with their most important trading partner, the EU.

Since the collapse of the USSR, despite geographical proximity and undoubted need, no mechanism for economic and political cooperation has been developed between Russia and the EU. The establishment of the EAEU has given the opportunity to create a platform for cooperation and the normalization of mutual relations with the European Union (Khitakhunov et al. 2016). The second important plane in the international relations that the Eurasian Economic Union can create is its relationship with China. The EAEU can become an effective instrument for formulating economic dialogue with this country. Although Russia, Kazakhstan and Kyrgyzstan belong to the Shanghai Cooperation Organization together with China, the EAEU seems to be more useful to them in the context of changes that the Chinese concept of The Belt and Road Initiative is provoking on the economic map of the world. On October 1, 2017, a joint statement from the Eurasian Economic Commission (EEC) and the Ministry of Commerce on the Principles of Trade and Cooperation in Hangzhou (China) was made (Eurasian Economic Commission 2018). Thanks to The Eurasian Economic Union (in fact, a part of it, i.e., the customs union), goods transported by land between China and the European Union cross only two customs boundaries: between China and the EAEU (customs union) and between the EAEU (customs union) and the European Union. This results in a number of interesting opportunities for the development of services and trade as well as transport and logistics infrastructure. This approach was adopted by researchers implementing the project "Challenges and Opportunities of Economic Integration within a Wider European and Eurasian Space" at the International Institute for Applied Systems Analysis. In the opinion of the researchers, thanks to the implementation of the "Lisbon to Vladivostok" cooperation concept, measurable benefits would be achieved by all participants in the following areas: trade, non-tariff barriers, energy, transport and infrastructure, the mobility of people, and others (Vinokurov et al. 2016).

Since the beginning of the EAEU's functioning, its possibilities to actually create political and economic relations with external entities, mainly from the European Union and China, have been examined and evaluated by scientists and practitioners. In the opinion of many researchers, the EAEU has been a symbol of Russian domination in the region (Dragneva and Wolczuk 2014), but it is also commonly pointed out that this does not exclude the organization's openness to links with the global economy (Khitakhunov et al. 2016) due to the participation of as many as 4 out of 5 Member States in the World Trade Organization, and WTO membership is considered as an important criterion for integration with the global economy (Żołądkiewicz 2010).

Many researchers find new qualities with this initiative, even if they assume that the EAEU is another attempt to strengthen Russia's position in the region. Dragneva and Wolczuk, writing about the EAEU, stress that this is "a new type of project, with 
ambitions to bring tangible benefits to their Member States and is a visible alternative to the European Union" (Dragneva and Wolczuk 2014, p. 8). However, the authors note that there are several institutional and systemic factors limiting the effectiveness of the EAEU (Dragneva and Wolczuk 2014, p. 8). In the latest publication by the authors, the results of their research lead them to the conclusion that "the union is mainly a Russia-led project and other members have exercised a significant influence over its direction" (Dragneva, Wolczuk 2017, p. 24).

In turn, Khitakhunov, Mukhamediyev and Pomfret (2016) point out that even if Russia perceives the Eurasian Economic Union as a symbol of its role and domination in the region, the EAEU itself is an open-outside integration project due to the participation of the majority of the member states being in the WTO. The issue of the possibilities offered by the EAEU in the formulation of external relationships of the entire grouping is also taken up in the studies presented by Blockmans, Konanyan and Vorobiov (2012), who point out that "the Eurasian Economic Commission has obtained a mandate for international negotiations with the European Union as if above the heads of the Member States". In the chapter entitled Uses of Eurasia: the Kremlin, the Eurasian Union, and the Izborsky Club Andrei P. Tsygankov reviews the research and forecasts on the Eurasian Economic Union and points out that many "global thinkers" perceive the EAEU as "a bridge connecting Europe and Asia" and an initiative that can bring both "regional and international" effects (Tsygankov 2016, p. 65). However, the author also presents the opinion that the success of the EAEU will depend on whether Russia manages to maintain a multi-vector relationship with all major European and Asian countries (Tsygankov 2016, pp. 65-66).

There are also some critical voices about the EAEU in the context of relations with China. Wilson (2016) argues that the EAEU and the BRI are a reflection of the tension between Russia and China. There are also researchers who perceive the EAEU as an initiative that is not compatible with the BRI and even directed against the Chinese influence in the region (Zank 2017).

A different approach is presented by experts from the Eurasian Development Bank, Center of Integration Studies, who, in the monograph "Silk Road Transport Corridors: Assessment of Trans-EAEU Freight Traffic Growth Potential”, focus on solutions that can be used to improve the functioning of the routes. They assume that, regardless of the current political background of the land routes, the BRI branches running through the territory of the EAEU are going to be developed (Vinokurov et al. 2018). 


\section{An assessment of the potential of the Eurasian Economic Union as an element of the Belt and Road Initiative}

The potential of the EAEU as an element of the RBI can be considered and researched on at least five levels:

a) the actual possibilities of the EAEU to create harmonious political and economic relations with China, the EU and other countries,

b) the implementation and actual application of the customs union rules for the transit of goods by the EAEU,

c) external factors and international structural factors,

d) geographical, technical and logistical potential for creating transport and logistics routes within the framework of the BRI,

e) skills and willingness to eliminate administrative, border and other barriers restricting the transit of goods through the territory of the BRI.

a) An important test for the Eurasian Economic Union, as well as a predictor of its development, will be the ability to develop an economic platform for cooperation with the European Union and China (Czerewacz-Filipowicz 2016). The EAEU authorities have competences to conclude and negotiate international agreements. The problem lies in Russia's relations with the EU and the resulting embargo. The Eurasian Development Bank Center of Integration Studies draws the attention to the potential of the EAEU in the context of creating trade routes between Europe and China, Asia or other geographic directions in many of its reports and analyses. In the official EAEU documents and the reports of integration institutions (e.g., EDB CIS), the role that the Eurasian Economic Union can play in the BRI (Vinokurov et al. 2018) is underlined. However, it should not be forgotten that the EAEU can be a platform to negotiate with the EU or China for the Member States, but it does not have to. Both Armenia and Kazakhstan have concluded agreements with the EU. Belarus has also "made a number of overtures to improve relations with the EU” (Dragneva and Wolczuk 2017, p. 22). In addition, the individual EAEU countries have chosen a number of individual initiatives and collaborated with China on the Belt and Road Initiative, independently of the EAEU. An example here might be the Special Economic Zones in Belarus: Grodnoinvest or Industrial Park Great Stone. In Kazakhstan, the Khorgos Free Economic Zone ("Khorgos - Eastern Gates"), one of the most spectacular projects of the BRI, was established on the Chinese-Kazakh border as part of the cross-border cooperation related to the Belt and Road Initiative. The implementation of the project has had a significant impact on economic and trade relations between the Eurasian countries and it will become a strategic logistics center connecting China, Central Asia and the Middle East (Khorgos - Eastern Gate 2018). The investment was necessary to improve the efficiency of the main corridors of the BRI aimed at Central Asia, Russia and Europe through Kazakhstan (Baizakova et al. 2017). The zone is part of the Eurasian transit bridge, between the Chinese port of Shanghai and the EU, and is an important point for building rail connections between China and Europe (Kazakhstan: Special Economic Zones 2016). 
b) The customs union between Belarus, Kazakhstan and the Russian Federation started its operations on January 1, 2010. The Common Customs Code came into force six months later. In 2014, when the agreement for the EAEU entered into force, the customs union became an integral part of it. By definition, the functioning of the customs union should greatly facilitate the activities taken up within the framework of the BRI. The main expected benefits are the possibility to cross only two customs borders on the route between European countries and China, that is, between the EU and the customs union and between the customs union and China. It should result in faster and cheaper transit, fewer transport formalities as well as greater competitiveness of the BRI land routes.

The actual assessment of the customs union from the perspective of the BRI, however, is very ambiguous. In the report "Belt and Road Transport Corridors: Barriers and Investment", the researchers studying the main barriers to the development of the BRI in the EAEU area state that "border/customs formalities in the EAEU member currently do not represent a serious barrier to international transit and trade" (Lobyrev et al. 2018, p. 22). In addition, they indicate that the Customs Code of the Eurasian Economic Union, which came into effect on January 1, 2018, introduced a series of improvements and electronic solutions (EEC 2018), due to which the time required for the completion of border/customs formalities is an average of 2 hours (Lobyrev et al. 2018, p. 24). The document "sets a limit on the time that the customs authority may spend on completing customs formalities at four hours" (Lobyrev et al. 2018, p. 23).

A somewhat different view on the transit of goods from Europe to China through the customs union is presented by the researchers from the Centre for Eastern Studies. In their opinion, Russia's policy limits the transit of some European goods to China through the territory of Russia. In spite of the fact that according to the Russian regulation international transit is excluded from the sanctions and embargo regime, some goods, among others, meat and fruit, are blocked by Russian customs officers (Jakóbowski et al. 2018, p. 45).

c) Among the many external and structural factors that affect the assessment of the Eurasian Economic Union as part of the BRI, two seem to be particularly important: (1) the structure of trade between the EU-China and the EAEU-China; and related to it, (2) the issue of the disproportionate use of containers (Kuźmicz and Persch 2017) transporting goods from China to the EU and the EAEU and from the EU and the EAEU to China.

China is the largest exporter and the second largest importer in the world. The value of China's trade in goods in 2017 amounted to 3,640 billion euros, of which 2,018 billion euros was exported and 1,622 billion euros was imported. In 2017, China reached a surplus of foreign trade turnover, amounting to 396 billion euros (European Commission 2018). This means that most countries in the world have a deficit in trade with China, which also applies to the EU, taken as a whole, and the EAEU countries. The EU countries still remain China's largest trading partner. The value of bilateral trade at the end of 2017 amounted to 549 billion euros. Chinese exports to the EU in 2017 were worth 332 billion euros, and the value of imports from EU countries amounted to 217 billion euros (European Commission 2018). 
In turn, in the case of the Russian Federation, China's imports in 2017 amounted to 34,5 billion euros, and exports 42,5 billion euros, Kazakhstan: imports - 4,2 billion euros, and exports - 5,1 billion euros, Belarus respectively: 2,4 billion euros and 0,3 billion euros (European Commission 2018). Among the countries of the European Union, Germany is the only country with a trade surplus with China, while in the case of the EAEU, a small surplus is recorded by Kazakhstan.

Goods transported through the EAEU territory to China come from either the EU or the EAEU countries, so the deepening trade deficit of both structures with China means that trains returning to China are often partially empty. This disadvantageous trend, from the point of view of transport profitability, is additionally aggravated by the turnover structure between the EU and the EAEU, and China. Certain groups of goods suitable for container transport can be transported by means of rail transport, and hence they can also be shipped using multiple modes of transportation. The train is not always an appropriate means of transport for, e.g., raw materials or unprocessed metals or some agricultural products (so-called agricultural raw materials) as well as many industrial goods. It is profitable to transport high-value goods and capital-intensive goods (Jakóbowski et al. 2018, p. 6).

When examining the structure of trade between the EU and China, it can be concluded that the structure of commodity exports from China is dominated by industrial products (about 95\%), with a tiny share of agri-food products and raw materials. The most important export goods are office machines and telecommunications equipment (over 21\%), electric and non-electric machines (about 19\%), chemical industry products (about 5.8\%), textiles and clothing (about 5.1\%) and transport equipment (approx. 4.3\%). On the other hand, in the commodity structure of China's imports with the EU, the largest share is held by electric and non-electrical machinery (28.3\%), raw materials and fuels (about 23.8\%) other consumer goods (about 7.8\%), office machines and telecommunications equipment (7.1\%), vehicles, their parts and accessories (about 6.1\%) and agri-food products (about 3.5\%) (European Commission 2018).

This structure of trade means that more goods exported from China to the EU can be transported in containers than in the opposite direction, that is, from the EU to China. This is reflected in the current flow of goods. Approximately, " $90 \%$ of cargo brought to the EU from China is carried in containers, while from the EU to China it is about 70-75\%" (Vinokurov 2018, p. 7).

In the case of the EAEU, the "Fuel" commodity group dominates the structure of exports to China (65\%), followed by "timber, cork and timber/cork products" (17\%), "mineral and chemical raw materials "(9\%) and fertilizers (4\%). The commodity structure of the EAEU imports from China is much more diversified. First place is taken by "machinery, equipment and industrial products" (30\%), followed by "metal and metal products" (16\%), "finished chemical products", "finished construction materials" and "food and agricultural raw materials" at approximately $10 \%$ each as well as "mineral and chemical raw materials" with "clothing, footwear, textiles" accounting for 6-8\% each (Vinokurov 2018, pp. 54-55). This struc- 
ture of trade means that only $1.5-2 \%$ of goods exported by the EAEU countries can be transported in containers (Vinokurov 2018, p. 55).

According to research by the Eurasian Development Bank in 2016, 50,000 $\mathrm{FEU}^{2}$ was exported from China to the EU, and 25,000 FEU from the EU to China. In turn, 35,000 FEU went from China to the Eurasian Economic Union, and 10,000 FEU in the opposite direction (Vinokurov 2018, p. 51). Despite such large disproportions, the number of trains servicing the rail sector of the BRI has been growing rapidly since 2011. In total, there were 6637 rail freights in both directions between the EU and China, with 3673 rail freights in the record year of 2017. Such dynamics are, however, largely due to subsidies provided by the Chinese authorities, which in 2016 alone amounted to USD 88 million, which gives about USD 2,500 per FEU (Vinokurov 2018, p. 8). This means that when there is another reduction in subsidies granted by the Chinese government after 2020, this may weaken the dynamics of developing the railway connections within the BRI.

d) The geographical location between China and the European Union is one of the EAEU's greatest assets in the context of the railroads of the Belt and Road Initiative. In addition, an undeniable advantage is that in the EAEU Member States, as in China, the railways are an important and widely used means of transport. For this reason, several routes of the BRI, along with its branches, have been marked out through the territory of the EAEU (Map 1).

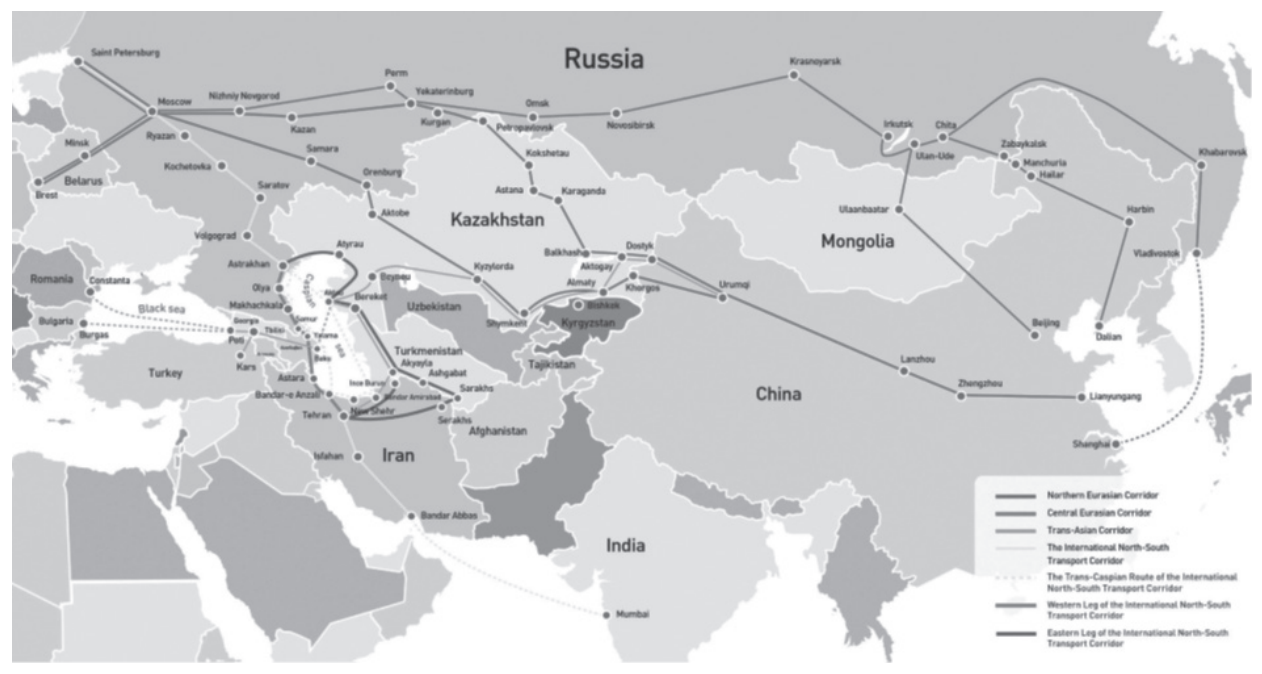

Map 1. The Belt and Road Initiative main corridors running through the Eurasian Economic Union Source: Lobyrev V., Tikhomirov A., Tsukarev T., Vinokurov E. (2018) Belt And Road Transport Corridors: Barriers And Investments, Report No. 50. Saint Petersburg: Eurasian Development Bank. Available at: https://eabr.org/upload/iblock/245/EDB-Centre_2018_Report-50_Transport-Corri dors_ Barriers-and-Investments_ENG.pdf (accessed: 15.07.2018), pp. 6-7.

2 FEU - Forty-Foot Equivalent Unit, a conventional unit used to describe the cargo capacity of container carriers and container terminals. 
The Northern Corridor uses the Russian Trans-Siberian railway line. Passing through Russia, the northern corridor approaches Belarus and Poland as a gateway to Europe. This corridor is currently being exploited. It passes through the smallest number of countries; therefore it involves a minimum number of border crossings and only two customs boundaries. In China, this corridor includes at least two route options. The first of these starts in Beijing and runs through Tianjin, the Hebei region to Hohhot, to Mongolia and on to Russia. In the second variant, the route begins in Dalian, then passing Harbin before reaching the Russian city of Chita. The corridor is part of the "Steppe Road trajectory" planned in Mongolia, which involves the construction of road connections between China and Russia in Mongolia.

The next corridor, the "New Eurasian Land Bridge Economic Corridor", connects the Chinese city of Xinjang with the countries of Western Europe. The corridor route is marked out by Kazakhstan, Russia and Belarus to Poland, where goods cross the borders of the European Union (the route continues to Germany, the Netherlands, and Spain).

The transit corridor running from Russia through Ukraine to the European Union is not shown on the map due to the fact it is almost completely blocked by the Russian Railways.

The transport corridor China-Central Asia, East Asia, which connects China with the Arabian Peninsula, runs through the territory of the Eurasian Economic Union. The corridor begins in Xinjiang and, going through Central Asia, it reaches the Persian Gulf, the Mediterranean Sea and the Arabian Peninsula. Its route runs through two countries of the EAEU: Kazakhstan and Kyrgyzstan, and seventeen countries and regions of Central Asia. It is of great importance to China because of the possibility of transporting oil and natural gas from the Arabian Peninsula, Turkey and Iran to Xinjiang (Barisitz and Radzyner 2017).

Due to the conflict between Russia and Ukraine and the war in Ukraine, almost all rail transport from China to the European Union crosses the Eurasian Economic Union - European Union border in Poland, mainly in Małaszewicze. A small number of goods from Belarus are directed north through Lithuanian and Latvian ports.

The crossing point Brest (Belarus) - Malaszewicze (Poland) is definitely not large enough at this time to handle such traffic, especially since the border crossing itself leaves much to be desired. According to some, the Polish side is unable to meet its obligations in the form of servicing 14 trains a day, as it services only 9-10 (Lobyrev et al. 2018, p. 8). According to others, the problem lies with the infrastructure on the Belarusian side of the border crossing (Jakóbowski et al. 2018). The fact remains, however, that the development of railroads of the BRI across the territory of the EAEU requires new Polish-Belarusian border crossings servicing the BRI trains, e.g., at the Bruzgi-Kuźnica Białostocka and Swislocz-Siemianówka crossings.

e) There are many types of barriers to the development of the Belt and Road Initiative in the EAEU area related to:

- railway infrastructure,

- border/customs-related barriers and non-tariff barriers,

- legal and administrative issues. 
The width of tracks between the EU, China and the EAEU countries differs. According to experts, the technical activities related to container transshipment or bogie exchange do not take more than 2 to 6 hours for individual trains (Lobyrev et al. 2018, p. 9). The quality of railway infrastructure, that is, the tracks, electrification, control systems and other elements, as well as logistic infrastructure, varies significantly in individual regions of the EAEU. However, it should be noted that in Russia, Kazakhstan, Belarus and Kyrgyzstan, a number of railway and logistics investments are being implemented to improve the functioning of individual routes. Many of them are financed from the funds of the Asian Infrastructure Investment Bank and some from the Eurasian Development Bank.

Customs issues at the external borders of the EAEU were discussed earlier in the article and seem to be a problem mainly for suppliers of certain goods from the EU. However, since the difficulties do not result directly from customs regulations, but from the preservation and interpretation of the Russian embargo by the Russian customs administration, they should be included in non-tariff barriers.

The current capacity at the border between the EU and the EAEU is also a problem. Due to the conflict between Russia and Ukraine, routes running through their territory cannot be used. Therefore, investments on the Polish-Belarusian border and new logistics hubs are indispensable.

Significant differences in the transport law between the EU, the EAEU and China generate a whole catalog of administrative and legal difficulties. To a large extent, they are derived from various conventions regulating rail transport adopted in individual countries. The problem is also made by various regulations in the EU, the EAE and China regarding the permissible length of trains.

\section{Conclusions}

The railway part of the Belt and Road Initiative is supported and subsidized by China, as it is an important factor supporting the development of the less developed western and north-western provinces of the country. The Eurasian Economic Union countries are located on the BRI route due to its geographical location. The article does not assess whether the EAEU countries will participate in the BRI or not but to what extent the EAEU is a structure that has the potential and opportunity to actively contribute to and shape the BRI. Alternatively, maybe it will be replaced by bilateral negotiations conducted with China by individual countries of the EAEU.

The current political situation suggests that although the EAEU has developed appropriate legal and administrative instruments to create beneficial economic and political relations with the EU, the conflict between Russia and the EU, and the mutual embargos, prevent a dialogue. In the case of China, the EAEU has been negotiating a cooperation agreement. The shape and, more importantly, the implementation of this agreement will be a test of competence of the EAEU. 
Another challenge and barrier to the development of the BRI is not directly related to the functioning of the Eurasian Economic Union. The problem lies in the structure and the volume of trade between the EU and China and between the EAEU and China. The BRI railroad needs driving factors to get developed. The current train subsidies by the Chinese government are not a solution here. The Russians and many EU countries are looking for possibilities to export new goods to the Chinese market, preferably those that can be transported in containers. Perhaps, following Ewa Oziewicz (2015), luxury goods, for which demand in China is growing dynamically, may be in some part an opportunity to solve the problem of empty containers. Another solution could be direct regular connections between factories located in the EU and China. In the case of merging factories, the companies rent entire trains to transport their products, gaining on price and transport time. Due to the fact that one train transports far fewer containers than a ship, it can be completed by one company alone (Jakóbowski et al. 2018, p. 12). In addition, both Russia and the EU countries are seeking to increase the share of their agricultural products on the Chinese market.

A number of administrative barriers could be resolved if there were a dialogue between the EU and the EAEU; some of the barriers are relatively easy to eliminate. Most of the technical problems, in particular in Central Asia, can be solved thanks to investments financed by the Asian Infrastructure Investment Bank.

Paradoxically, against the background of other problems and using container and intermodal transport, the different track gauges in the EAEU, the EU and China are not a particular problem. Undoubtedly, however, it is necessary to invest in the development of border infrastructure between Poland and Belarus, on both sides of the border.

\section{References}

Baizakova, Z., Parkhomchik, L., Simsek, H.A. (2017), The Khorgos Free Economic Zone and its economic potential, Eurasian Research Institute weekly e-bulletin, No. 97. Available at: http://eurasian-research.org/sites/default/files/Weekly_\%20e-bulletin_2.01.2017-9.01.2017_No\%2097.pdf (accessed: 25.07.2018).

Barisitz, S., Radzyner, A. (2017) The New Silk Road, part I: a stocktaking and economic assessment, [in:] Backé, P. (ed.), Focus on European economic integration, Oesterreichische Nationalbank, Vienna.

Bhagwati, J., Panagariya, A. (1996), The Economics of Preferential Trade Agreements, AEI Press, Washington.

Blockmans, S., Kostanyan, H., Voroviov, I. (2012), Towards Eurasian Economic Union: The challenge of integration and unity, "CEPS Special Report”, No. 75.

Bond, I. (2017), The EU, the Eurasian Economic Union and One Belt, One Road: Can they work together?, Centre for European Reform.

Czerewacz-Filipowicz, K. (2016), Regionalizm i regionalizacja w Euroazjatyckiej Unii Gospodarczej. Wpływ EAUG na integrację handlowa państw członkowskich z gospodarka światowa [Regionalism and regionalization in the Eurasian Economic Union. 
The influence of the EAEU on trade integration of the Member States into the world economy], Oficyna Wydawnicza Politechniki Białostockiej, Białystok.

Czerewacz-Filipowicz, K., Konopelko, A. (2017), Regional Integration Processes in the Commonwealth of Independent States, Economic and Political Factors, Springer, Cham.

De Lombaerde, P. (ed.) (2007), Multilateralism, Regionalism and Bilateralism in Trade and Investment, Springer, Dordrecht and New York.

Dragneva, R., Wolczuk, K. (2014), Eurasian Economic Integration: Institutions, Promises and Faultlines, [in:] Cadier, D. (ed.), The Geopolitics of Eurasian Economic Integration, LSE: IDEAS Report, London.

Dragneva, R., Wolczuk, K. (2017), The Eurasian Economic Union Deals, Rules and the Exercise of Power, Chatham House, the Royal Institute of International Affairs, London.

Eurasian Economic Commission (EEC) (2018), Tamozhennyy kodeks EAES vstupil vsilu. January 1. Available at: http://www.eurasiancommission.org/ru/nae/news/ Pages/01-01-2018-1.aspx. (accessed: 25.08.2018).

Eurasian Economic Commission. Available at: http://www.eurasiancommission.org/ en/nae/news/ Pages/2-10-2017-5.aspx (accessed: 25.08.2018).

Jakóbowski, J., Popławski, K., Kaczmarski, M. (2018), The Silk Railroad. The EU-China rail connections: background, actors, interests, OSW Studies No. 72, Centre for Eastern Studies, Warsaw.

Kazakhstan: Specjal Economic Zones. Available at: http://invest.gov.kz/uploads/ files/ 2016/01/26/special-economic-zones-of-the-republic-of-kazakhstan-2013.pdf (accessed: 25.07.2018).

Khitakhunov, A., Mukhamediyev, B., Pomfret, R. (2016), Eurasian Economic Union: present and the future perspectives, Economic Change and Restructuring, Springer.

Kuźmicz, K.A., Pesch, E. (2017), Prerequisites for the modelling of empty container supply chains, "Engineering Management in Production and Services", Vol. 9 Issue 3.

Libman, A. (2016), Linking the Silk Road Economic Belt and the Eurasian Economic Union: Mission Impossible?, "Caucasus International”, No. 1 (6).

Lobyrev, V., Tikhomirov, A., Tsukarev, T., Vinokurov, E. (2018), Belt And Road Transport Corridors: Barriers And Investments, Report No. 50. Saint Petersburg: Eurasian Development Bank. Available at: https://eabr.org/upload/iblock/245/EDB-Centre_2018_Report-50_Transport-Corridors_Barriers-and-Investments_ENG.pdf (accessed: 15.07.2018).

Miklaszewski, S., Molendowski, E. (ed.) (2009), Gospodarka światowa w warunkach globalizacji i regionalizacji rynków, Difin, Warsaw.

Oziewicz, E. (2015), Uwagi na temat chińskiego rynku zbytu towarów konsumpcyjnych ze szczególnym uwzględnieniem dóbr luksusowych, "Annales Universitatis Mariae Curie-Skłodowska, Sectio H Oeconomia”, Vol. XLIX(2).

Putin, W. (2011), Новый интеграционный проект для Евразии - будущее, которое рождается сегодня. Available at: http://izvestia.ru/news/502761 (accessed: 25.07.2018).

SEZ Khorgos Eastern Gates, about SEZ “Khorgos - Eastern Gate”. Available at: http:// www.sezkhorgos.kz/about-eng (accessed: 25.07.2018). 
Treaty on the Eurasian Economic Union. [Договор о Евразийском экономическом союзе] (2014), https://docs.eaeunion.org/ru-ru/Pages/DisplayDocument.aspx?s=bef9c798-3978-42f3-9ef2-d0fb3d53b75f\&w=632c7868-4ee2-4b21-bc64-199 $5328 \mathrm{e} 6 \mathrm{ef} 3 \& \mathrm{l}=540294 \mathrm{ae}-\mathrm{c} 3 \mathrm{c} 9-4511-9 \mathrm{bf} 8-\mathrm{aaf5d} \mathrm{ee} 0 \mathrm{~d} 169 \&$ EntityID=3610 (accessed: 5.01.2016).

Tsygankov, A.P. (2016), Uses of Eurasia: the Kremlin, the Eurasian Union, and the Izborsky Club, [in:] Suslov, M., Bassin, M.,. Boulder, L. (eds.), Eurasia 2.0: Russian Geopolitics in the Age of New Media, Lexington Books, New York, London.

Vinokurov, E., Balas, P., Emerson, M., Havlik, P., Pereboyev, V., Rovenskaya, E., Stepanova, A., Kofner, J., Kabat, P. (2016), Challenges and Opportunities of Economic Integration within a Wider European and Eurasian Space, International Institute for Applied Systems Analysis, Laxenburg, Austria.

Vinokurov, E., Lobyrev, V., Tikhomirov, A., Tsukarev, T. (2018), Silk Road Transport Corridors: Assessment of Trans-EAEU Freight Traffic Growth Potential, Report No. 49. Saint Petersburg: Eurasian Development Bank. Available at: https://eabr. org/en/analytics/integration-research/cii-reports/silk-road-transport-corridors-assessment-of-trans-eaeu-freight-trafficgrowth-potential-/ (accessed: 15.07.2018).

Wilson, J.L. (2016), The Eurasian Economic Union and China's silk road: implications for the Russian-Chinese relationship. "European Policy and Society", No. 17 (1).

Zank, W. (2017), The Eurasian Economic Union: A Brittle Road Block on China's 'One Belt - One Road' - A Liberal Perspective, "The Journal of China and International Relations", No. 5 (1).

Żołądkiewicz, K. (2010), Accession to the WTO. Case: The Russian Federation, International, "Journal of Emerging and Transition Economies", 2010, Vol. 3, No. 1.

\section{Streszczenie}

\section{Euroazjatycka Unia Gospodarcza jako element Inicjatywy Pasa i Drogi}

Nowy Jedwabny Szlak, a właściwie Inicjatywa Pasa i Drogi (IPD) to chińska inicjatywa mająca na celu ułatwienie handlu międzynarodowego między Chinami i Europą oraz Afryką, budowę nowego międzynarodowego ładu gospodarczego i systemu bezpieczeństwa. W IPD zaangażowanych jest obecnie ponad 60 państw należących do różnych ugrupowań gospodarczych, charakteryzujących się różnym poziomem rozwoju gospodarczego i otwartości ekonomicznej.

Wiele odnóg lądowego Nowego Jedwabnego Szlaku biegnie przez państwa należące do Euroazjatyckiej Unii Gospodarczej (EAUG). W tym głównie korytarz transsyberyjski będący północną odnogą Szlaku, który rozwija się w sposób najbardziej dynamiczny i jest w największym stopniu eksploatowany spośród wszystkich kolejowych połączeń między Chinami i Europą.

Euroazjatycka Unia Gospodarcza i funkcjonująca w jej ramach unia celna między Białorusią, Kazachstanem i Rosją teoretycznie powinny umożliwiać łatwy tranzyt towarów między Europą i Azją. Znacznie lepsza, niż w przypadku pozostałych odnóg 
kolejowych IPD, infrastruktura transportowa wydaje się być dodatkowym atutem. Niestety czynniki polityczne i embargo nałożone przez Rosję na wiele towarów pochodzących z Europy Zachodniej, znacznie ograniczają możliwości wykorzystania tego szlaku transportowego.

Celem artykułu było zbadanie potencjału Euroazjatyckiej Unii Gospodarczej jako elementu Inicjatywy Pasa i Drogi. Ocena możliwości wykorzystania biegnącego przez terytorium EAUG korytarza transportowego w ramach IPD, a także identyfikacja głównych determinant, które w przyszłości będą oddziaływały na rozwój biegnących przez EAUG korytarzy transportowych i logistycznych.

Słowa kluczowe: Euroazjatycka Unia Gospodarcza, Inicjatywa Pasa i Drogi, Nowy Jedwabny Szlak, handel międzynarodowy. 